\title{
ESTIMASI PARAMETER MODEL GRAVITY DENGAN METODE PENAKSIRAN KUADRAT TERKECIL DAN FUNGSI HAMBATAN EKSPONENSIAL NEGATIF (STUDI KASUS KABUPATEN SUKOHARJO)
}

\author{
Josephin Onesifera Rum ${ }^{1)}$, Syafi'i'i'), Slamet Jauhari Legowo ${ }^{3)}$ \\ 1) Mahasiswa Fakultas Teknik, Prodi Teknik Sipil, Universitas Sebelas Maret \\ 2), 3) Pengajar Fakultas Teknik, Prodi Teknik Sipil, Universitas Sebelas Maret \\ Jl. Ir. Sutami 36A, Kentingan Surakarta 57126; Telp. (0271) 634524, Fax 662118 \\ Email: josephinr@student.uns.ac.id
}

\begin{abstract}
Sukoharjo Regency has a strategic location, located at the junction between Semarang, Yogyakarta, and Surakarta. It is also supporting the development in Sukobarjo Regency, and increasing movement. Increased movement causes transportation problems, therefore planning is needed by estimating the OD-matrix. This study was conducted to determine the value of $\beta$ in the Negative Exponential deterrence function and the LeastSquare method, to determine the total estimated distribution of movement in the Sukoharjo Regency in 2021, and to know the coefficient of determination by comparing traffic flow from model and from traffic count. Estimation of OD-Matrix for the coming year uses the Gravity Model. To get the value of $\beta$ in the Gravity Model equation was using the Newton-Raphson calibration method with Matlab software. The results of this study obtained the value of the parameter $\beta$ of 0.0613, with the total movement of Sukoharjo Regency in 2021 is 16.364 pcu/ hour. The validity of this study is considered very high for earned value R2 of 0.8194 .
\end{abstract}

Keywords: EMME/3, Matlab, Model Gravity, OD-Matrix

\begin{abstract}
Abstrak
Kabupaten Sukoharjo memiliki lokasi yang strategis, yakni letaknya di persimpangan Semarang, Yogyakarta, dan Surakarta. Hal ini akan mendukung pembangunan di Kabupaten Sukoharjo, dan meningkatkan pergerakan. Pergerakan yang meningkat menimbulkan masalah transportasi, oleh karena itu diperlukan perencanaan dengan mengestimasi matriks asal tujuan. Tujuan dari penelitian ini diharapkan dapat diketahui besarnya parameter $\beta$ pada fungsi hambatan Eksponensial-Negatif dengan metode Kuadrat Terkecil, untuk mengetahui total estimasi distribusi pergerakan di Kabupaten Sukoharjo pada tahun 2021, serta menguji tingkat kemiripan arus lalu lintas hasil pemodelan dan hasil traffic count. Perhitungan estimasi distribusi pergerakan tahun mendatang menggunakan Model Gravity. Nilai parameter $\beta$ dalam persamaan model Gravity didapatkan melalui kalibrasi Newton-Raphson pada software Matlab. Untuk mengukur tingkat kemiripan dari perhitungan arus lalu lintas hasil pemodelan dan hasil traffic count digunakan Koefisien Determinasi. Hasil dari penelitian ini didapatkan nilai parameter $\beta$ sebesar 0,0613, dengan total pergerakan Kabupaten Sukoharjo pada tahun 2021 adalah 16364 smp/jam. Tingkat validitas dari penelitian ini dianggap sangat tinggi karena didapatkan nilai R2 senilai 0,8194.
\end{abstract}

Kata Kunci : EMME/3, Matriks Asal Tujuan, MATLAB, Model Gravity

\section{PENDAHULUAN}

Perkembangan suatu wilayah salah satunya dipengaruhi oleh pergerakan yang terjadi. Efisiensi ekonomi dan sosial akan terpengaruh oleh pergerakan pemenuhan kebutuhan yang terjadi. Adanya dilakukan akan menimbulkan permasalahan transportasi. Hal ini dikarenakan permintaan pergerakan yang meningkat akibat kebutuhan yang semakin meningkat. Munculnya masalah transportasi perlu disikapi secara cermat oleh pemerintah sebagai pembuat kebijakan, dengan didasari besarnya kebutuhan pergerakan yang akan terjadi.

Besarnya kebutuhan pergerakan dapat diketahui dengan perencanaan menggunakan konsep Four-Step Model. Pada konsep ini tahap perencanaan dimulai dari mengetahui potensi pergerakan yang akan terjadi, sehingga dapat menghasilkan akses yang layak dan memadai untuk digunakan. Salah satu sub-model yang ada dalam konsep ini yaitu trip distribution, dilakukan estimasi sebaran pergerakan yang meninggalkan zona asal menuju zona tujuan. Hasil sebaran pergerakan digambarkan dengan Matriks Asal Tujuan (MAT) atau desire line. MAT tahun mendatang diestimasi menggunakan metode sintesis. Metode ini dilakukan untuk memodelkan hubungan antar pola pergerakan, hasil pemodelan akan digunakan untuk mengestimasi pola pergerakan masa mendatang. Distribusi pergerakan masa mendatang dapat diestimasi dengan model Gravity, dalam persamaan model Gravity terdapat nilai parameter untuk mengestimasi sebaran pergerakan pada tahun mendatang. 
Studi kasus untuk penelitian ini yaitu Kabupaten Sukoharjo yang memiliki lokasi yang strategis, yakni letaknya di persimpangan menuju Semarang, Yogyakarta, Solo. Hal ini mendukung perkembangan pembangunan di Kabupaten Sukoharjo. Perkembangan pembangunan yang terjadi akan sejalan dengan meningkatnya pergerakan. Hal ini menunjukkan kemungkinan terjadinya permasalahan transportasi yang akan terjadi apabila tidak segera diatasi. Oleh karena itu perlunya perencanaan transportasi dengan memperhatikan kebutuhan pergerakan. Studi kasus dilakukan untuk mengestimasi besar pola pergerakan asal tujuan dengan pendekatan Model Gravity, dimana fungsi hambatan yang digunakan yaitu Eksponensial-Negatif dengan penyelesaian menggunakan metode Kuadrat Terkecil.

\section{DASAR TEORI}

\section{Model Gravity}

Menurut Tamin (2000) model Gravity merupakan pengembangan dari analogi hukum gravitasi, dimana dalam hukum gravitasi gaya tarik menarik dipengaruhi oleh massa 2 benda dan jarak kedua benda. Konsep gravitasi dalam konteks perencanaan transportasi yaitu pergerakan dipengaruhi trip generation dan aksesibilitas dari zona asal menuju zona tujuan. Trip generation disamakan dengan massa 2 benda sementara aksesibilitas disamakan dengan jarak dua benda. Untuk memenuhi persamaan tersebut digunakan faktor penyimbang berupa batasan bangkitan dan tarikan. Sehingga didapatkan persamaan sebagai berikut :

$T_{i d}=O_{i} \cdot D_{d} \cdot A_{i} \cdot B_{d} \cdot f\left(C_{i d}\right)$

keterangan :

$T_{i d} \quad=$ total pergerakan dari zona asal menuju zona tujuan

$A_{i}, B_{d}=$ faktor batasan bangkitan, batasan tarikan

$O_{i} \quad=$ total pergerakan yang dibangkitkan dari zona asal

$D_{d} \quad=$ total pergerakan yang tertarik menuju zona tujuan

$f\left(C_{i d}\right)=$ fungsi hambatan

Fungsi hambatan didefinisikan sebagai tolak ukur nilai aksesibilitas perpindahan dari zona asal menuju zona tujuan, seperti fungsi biaya, waktu, dan jarak. Menurut Hyman (1969) dalam buku Tamin (2000) terdapat beberapa fungsi hambatan dalam model Gravity :

1. Fungsi Hambatan Pangkat

2. Fungsi Hambatan Eksponensial-Negatif

3. Fungsi Hambatan Tanner

\section{Metode Kuadrat Terkecil}

Pada persamaan model Gravity terdapat nilai parameter $\beta$ yang belum diketahui nilainya, untuk mendapatkannya dapat digunakan metode Kuadrat Terkecil. Perhitungan pada metode ini dilakukan dengan meminimumkan selisih antara hasil pemodelan dengan data pengamatan. Metode penaksiran Kuadrat-Terkecil dirumuskan seperti pada persamaan [2].

$$
\frac{\partial S}{\partial \beta}=f=\sum_{i=1}^{N} \sum_{d=1}^{N}\left[\frac{2}{T}\left(T_{i d}-\hat{T}_{i d}\right) \cdot \frac{\partial T_{i d}}{\partial \beta}\right] \ldots \ldots \ldots \text { [2] }
$$

\section{Kalibrasi Newton-Raphson}

Parameter $\beta$ yang belum didapatkan dalam Persamaan [2] dapat diperoleh melalui Kalibrasi Newton-Raphson. Penyelesaian metode ini dilakukan dengan eliminasi matriks Gauss-Jordan. Persamaan yang digunakan sebagai berikut :

$$
h=-\frac{f}{\frac{\partial f}{\partial \beta}} .
$$


Nilai $h$ digunakan untuk mendapatkan nilai berikut:

$\beta_{1}=\beta_{o}+h$

\section{Indikator Uji Statistik}

Tingkat kemiripan arus lalu lintas hasil pemodelan dan traffic count ditentukan dengan indikator Koefisien Determinasi. Nilai $\mathrm{R}^{2}$ dijelaskan oleh analisis regresi linear.

$$
R^{2}=\frac{\sum_{i}\left(\hat{Y}_{i}-\bar{Y}_{i}\right)^{2}}{\sum_{i}\left(Y_{i}-\bar{Y}_{i}\right)^{2}}
$$

Pada tabel 1 dapat dilihat tingkat validitas suatu model dengan nilai $\mathrm{R}^{2}$ yang didapatkan.

Tabel 1. Rentang Koefisien Determinasi ( $\left.\mathrm{R}^{2}\right)$

\begin{tabular}{ll}
\hline Nilai $\mathbf{R}^{\mathbf{2}}$ & Keterangan \\
\hline $0,80-1,00$ & sangat tinggi \\
$0,60-0,80$ & tinggi \\
$0,40-0,60$ & cukup tinggi \\
$0,20-0,40$ & rendah \\
$0,00-0,20$ & sangat rendah \\
\hline
\end{tabular}

\section{METODE}

\section{Lokasi Penelitian}

Wilayah studi pada penelitian ini yaitu Kabupaten Sukoharjo yang berada di Provinsi Jawa Tengah. Kabupaten Sukoharjo berbatasan secara langsung dengan 6 Kabupaten/Kota yaitu Surakarta, Karanganyar, Gunungkidul, Wonogiri, Klaten dan Boyolali. Sistem pembagian zona pada penelitian ini berdasarkan kecamatan, sehingga didapatkan 12 zona internal. Zona eksternal yang ditambahkan merupakan zona yang dianggap sebagai akses dari dan menuju Kabupaten Sukoharjo, yang berbatasan secara langsung dengan 6 kabupaten/kota disekitarnya. Titik survei penelitian ditentukan berdasarkan klasifikasi fungsi ruas jalan dan ruas jalan yang dianggap mewakili pergerakan di Kabupaten Sukoharjo.

\section{Pengolahan Basis Data}

Pengolahan data awal yang diperlukan untuk membentuk jaringan jalan pada software EMME/3. Pengolahan data diawali dengan memasukan nilai koordinat ruas jalan, dilanjutkan dengan perhitungan kapasitas jalan, kecepatan, dan waktu tempuh. Selanjutnya hasil survei volume lalu lintas dikalikan nilai ekivalen mobil penumpang sehingga dihasilkan data volume lalu lintas dengan satuan smp/jam. Kemudian dilanjutkan dengan mengestimasi nilai awal matriks (prior matrix).

\section{MAT Hasil Estimasi oleh EMME/3}

Basis data yang diperoleh dari tahap sebelumnya berupa koordinat, kapasitas jalan, kecepatan, waktu tempuh dan prior matrix akan dimasukkan ke dalam software EMME/3 dan dilakukan proses running. Dari proses tersebut didapatkan MAT hasil EMME/3. Hasil matriks tersebut akan diuji tingkat validitasnya.

\section{Kalibrasi Parameter Beta $(\beta)$}

Kalibrasi parameter $\beta$ pada fungsi hambatan Eksponensial-Negatif menggunakan kalibrasi Newton-Raphson, proses pengulangan perhitungan dilakukan hingga mencapai nilai $\beta$ yang tetap. Proses pengulangan tersebut dilakukan pada program MATLAB

\section{Estimasi MAT Hasil Pemodelan}

Estimasi MAT hasil model Gravity batasan bangkitan-tarikan didapatkan dengan memasukkan nilai $\beta$ hasil kalibrasi ke dalam Persamaan [1]. 


\section{Pembebanan Arus Lalu Lintas ke Jaringan Jalan}

Proses pembebanan sebaran pergerakan ke jaringan jalan dilakukan pada software EMME/3, dengan mengacu pada prinsip Wardrop Equilibrium yang pertama. Hasil dari pembebanan ini adalah arus lalu lintas pada ruas jalan.

\section{Uji Validasi}

Hasil arus lalu lintas pemodelan dan arus lalu lintas hasil survei dibandingkan dengan uji statistik Koefisien Determinasi $\left(\mathrm{R}^{2}\right)$. Uji validitas menunjukkan seberapa besar perbedaan antara kedua hasil arus lalu lintas tersebut.

\section{HASIL DAN PEMBAHASAN}

\section{Parameter Fungsi Hambatan}

Nilai parameter fungsi hambatan pada persamaan Model Gravity didapatkan melalui Kalibrasi Newton Raphson pada software Matlab. Pada awal perhitungan nilai estimasi $\beta$ awal sebesar 0,0800, kalibrasi dilakukan hingga mencapai batas konvergensi.

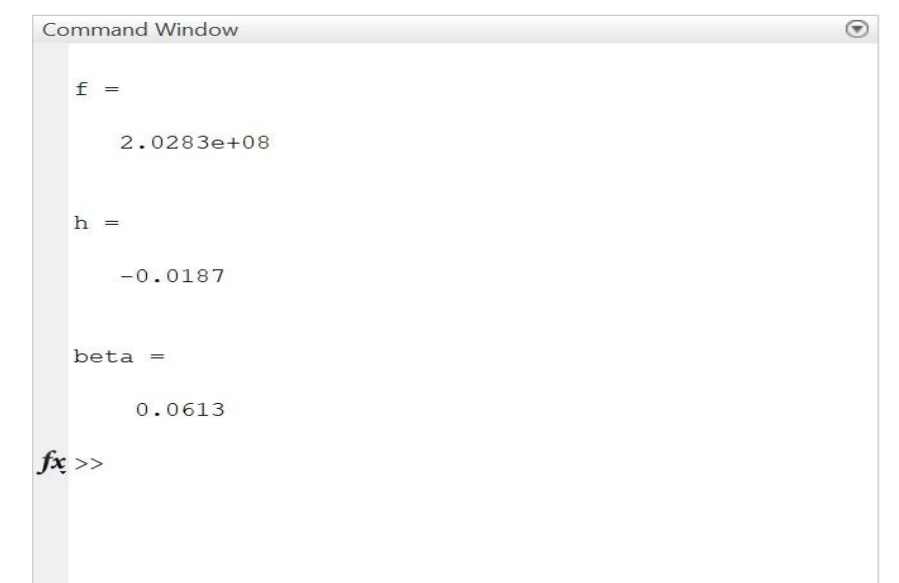

Gambar 1. Hasil Kalibrasi $\beta$ menggunakan software MATLAB

Tampilan dari hasil akhir perhitungan kalibrasi $\beta$ pada software MATLAB dapat dilihat pada Gambar 1. Dimana terdapat nilai f yang merupakan hasil perhitungan dari Persamaan [2], turunan pertama dari persamaan Metode Penaksiran Kuadrat Terkecil.. Nilai parameter $\beta$ yang belum didapatkan dalam Persamaan [2] dapat diperoleh melalui Persamaan [3], sehingga didapatkan nilai $h$ sebesar -0.0187 . Dari nilai $h$ tersebut didapatkan nilai $\beta$ sebesar 0,0613. 


\section{Estimasi Pergerakan Kabupaten Sukoharjo}

Dari hasil perhitungan diperoleh total pergerakan di Kabupaten Sukoharjo pada tahun 2021 sebesar 16364 smp/jam. Distribusi pergerakan dapat disajikan berupa MAT maupun desire line, dengan desire line pergerakan digambarkan dengan ketebalan yang berbeda berdasarkan besaran pergerakan antar zona.

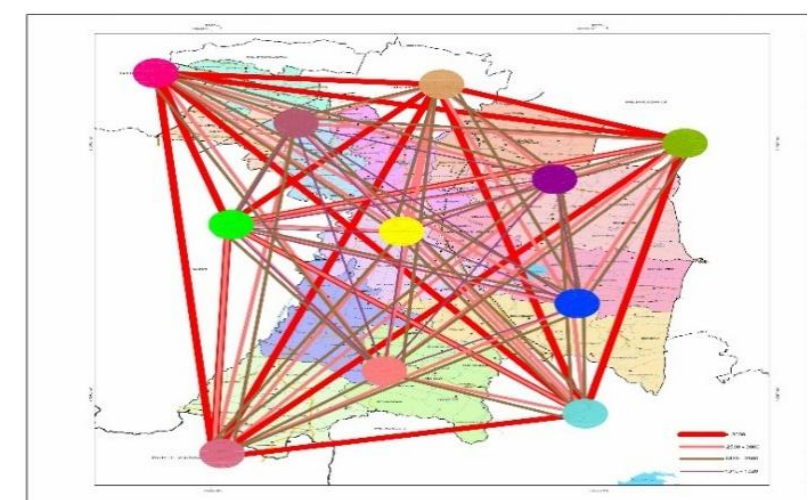

Gambar 2. Desire Line hasil estimasi pergerakan Tahun 2021

Pada Gambar 2. desire line pergerakan Kabupaten Sukoharjo digambarkan 11 titik di Kabupaten Sukoharjo, dimana zona internal digambarkan dengan 5 titik dan zona eksternal digambarkan dengan 6 titik. Titik-titik tersebut dibagi berdasarkan letak zona yang saling berdekatan. Dari desire line dapat dilihat bahwa garis pada zona eksternal-eksternal memiliki garis yang lebih tebal, hal ini menunjukkan bahwa zona eksternal-eksternal memiliki pergerakan terbesar dibanding pergerakan antar zona lainnya.

Tabel 2. Pergerakan Antar Zona

\begin{tabular}{lll}
\hline Jenis Pergerakan & Jumlah Pergerakan (smp/jam) & Persentase (\%) \\
\hline Internal-Internal & 1119 & 6,84 \\
Internal-Eksternal & 1491 & 9,11 \\
Eksternal-Internal & 2975 & 18,18 \\
Eksternal-Eksternal & 10780 & 65,88 \\
Jumlah & 16364 & \\
\hline
\end{tabular}

Pada tabel di atas dapat dilihat perbandingan pergerakan antar zona, dimana pergerakan zona eksternal-eksternal sebesar $10780 \mathrm{smp} / \mathrm{jam}(65,88 \%)$, kemudian pergerakan antar zona eksternal-internal sebesar $2975 \mathrm{smp} / \mathrm{jam}$ $(18,18 \%)$. Sementara itu untuk pergerakan zona internal-eksternal sebesar $1491 \mathrm{smp} / \mathrm{jam}(9,11 \%)$ dan pergerakan zona internal-internal menampilkan pergerakan yang tidak terlalu besar yaitu $1119 \mathrm{smp} / \mathrm{jam}(6,84 \%)$.

Hasil perhitungan menunjukkan pergerakan antar zona eksternal-eksternal memiliki nilai yang tinggi dibanding pergerakan antar zona lainnya. Hal ini dikarenakan lokasi Kabupaten Sukoharjo yang berbatasan dengan enam kabupaten/kota, sehingga pergerakan kabupaten/kota mempengaruhi pergerakan Kabupaten Sukoharjo. Adanya jaringan jalan arteri primer yang berada di Kabupaten Sukoharjo, yaitu Jalan Semarang-Solo memungkinkan adanya pergerakan antara Kabupaten Boyolali dan Kota Surakarta. Faktor lain yang perlu diperhatikan yaitu lokasi yang strategis berada di persimpangan Jogja, Solo, dan Semarang. Pergerakan dari ketiga kota tersebut yang tinggi akan mempengaruhi kawasan penyangga yang berada di sekitarnya.

Pergerakan antar zona eksternal-internal dan internal-eksternal memiliki karakteristik yang tidak jauh berbeda. Sukoharjo yang merupakan bagian Subosukawonosraten, terdapat interaksi antar wilayah tersebut dimana Surakarta menjadi pusatnya dengan wilayah lain menjadi kawasan penyangga. Kabupaten Sukoharjo yang bertumpu pada sektor pertanian dan sektor industri. Kawasan industri di Kabupaten Sukoharjo yang tersebar di Kecamatan Sukoharjo, Kecamatan Kartasura dan Kecamatan Grogol meningkatkan pergerakan. Pada ketiga wilayah tersebut tersebar beberapa industri skala besar dengan produksi besar, sehingga membutuhkan tenaga kerja yang banyak dari wilayah sekitar. Banyaknya tenaga kerja yang melakukan perjalanan menuju tempat kerja 
menimbulkan pergerakan yang cukup tinggi. Oleh karena itu pergerakan yang berasal dari wilayah sekitar Sukoharjo berdampak pada pergerakan zona eksternal-internal. Peran Kabupaten Sukoharjo lainnya sebagai kawasan penyangga bagi Surakarta, yaitu menjadikan wilayah Solo Baru sebagai kawasan pemukiman para pekerja yang beraktivitas di Solo. Namun dengan jumlah yang tidak terlalu banyak, pergerakan internal-eksternal yang timbul juga tidak sebesar pergerakan antar zona sebelumnya.

\section{Uji Validitas}

Nilai yang didapatkan dari uji validitas yaitu 0,8194 , nilai tersebut dapat dilihat pada grafik uji validitas pada software EMME/3 seperti pada Gambar 3. Hal ini menunjukkan pemodelan yang dilakukan memiliki tingkat validitas sangat tinggi, dimana selisih dari kedua data arus mencapai nilai yang minimum. Diketahuinya nilai $\mathrm{R}^{2}$ maka dapat diketahui pula galat yang terjadi sebesar 18,06\%. Galat yang timbul diakibatkan kesalahan pada data yang digunakan dalam pengolahan data.

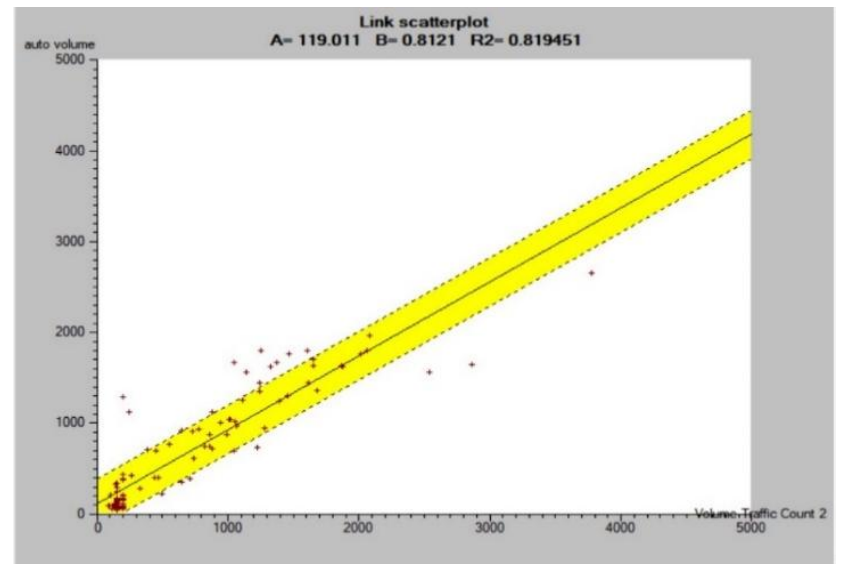

Gambar 3. Grafik Uji Validitas Menggunakan Software EMME/3

\section{SIMPULAN}

Berdasarkan pengolahan data dan analisis terhadap estimasi distribusi pergerakan Kabupaten Sukoharjo tahun 2021, dapat disimpulkan bahwa :

1. Nilai parameter $\beta$ pada fungsi hambatan Eksponensial Negatif sebesar 0,0613.

2. Total estimasi distribusi pergerakan Kabupaten Sukoharjo tahun 2021 sebesar $16.364 \mathrm{smp} / \mathrm{jam}$.

3. Pemodelan memiliki tingkat validitas yang sangat tinggi, dengan nilai sebesar 0,8194 .

\section{REKOMENDASI}

Beberapa hal yang dapat diperhatikan agar penelitian tentang estimasi distribusi pergerakan Kabupaten Sukoharjo yang selanjutnya dapat berkembang menjadi lebih baik yaitu :

1. Penambahan titik survei lalu lintas dengan lebih memperhatikan karakteristik ruas jalan yang akan disurvei.

2. Perhitungan kecepatan, waktu tempuh, dan kapasitas perlu memperhatikan kondisi dari tiap lajur.

3. Perlu adanya penelitian mengenai karakteristik pengguna jalan yang berpengaruh pada bangkitan dan tarikan pergerakan.

\section{UCAPAN TERIMAKASIH}

Terima kasih penulis sampaikan kepada Dr. Eng. Ir. Syafi'i , M.T. serta Slamet Jauhari Legowo, S.T., M.T. selaku dosen pembimbing dalam penelitian ini. Terima kasih kepada keluarga dan rekan-rekan yang selalu mendukung hingga penelitian ini dapat selesai.

\section{REFERENSI}

Abbas, Salim.,2000, "Manajemen Transportasi”, Cetakan pertama, Edisi kedua, Jakarta: Ghalia Indonesia. Anonim, 1997,” Manual Kapasitas Jalan Indonesia (MKJI) 1997”, Jakarta: Direktorat Jenderal Bina Marga Departemen Pekerjaan Umum RI. 
Elfa, M.Z., 2015, "Estimasi Matrik Asal Tujuan (Mat) dari Data Arus Lalu Lintas Dengan Metode Estimasi Kuadrat Terkecil Menggunakan Piranti Lunak Emme/3 (Studi Kasus Kota Surakarta)”, Skripsi, Surakarta: Fakultas Teknik Jurusan Sipil Universitas Sebelas Maret.

Fika, Z., Syafi'i., dan Slamet, Jauhari Legowo., 2016, "Estimasi Distribusi Perjalanan Kota Surakarta Tahun 2025 Menggunakan Model Gravity”, Skripsi, Surakarta: Fakultas Teknik Jurusan Sipil Universitas Sebelas Maret.

Hendarwati,P., 2014, "Estimasi Matriks Asal Tujuan Perjalanan Menggunakan Model Gravity dengan Fungsi Hambatan Eksponensial-Negatif di Kota Surakarta", Skripsi, Surakarta: Fakultas Teknik Jurusan Sipil Universitas Sebelas Maret.

Jamilah, W., Syafi'I, \& Handayani, Dewi.,2018, "Impact of Freight Transportation on Road Network Performance in Surakarta With Toll Road Scenario", AIP Conference Proceedings, 1977. https://doi.org/10.1063/1.5042987

Miro, F., 2005, "Perencanaan Transportasi untuk Mahasiswa", Perencana, dan Praktisi, Erlangga, Jakarta.

Nasution, 2004 dan 2008, "Manajemen Transportasi”, Ghalia Indonesia, Bogor.

Niken,Puspitasari., 2014, "Estimasi Matriks Asal Tujuan Perjalanan Menggunakan Model Gravity dengan Fungsi Hambatan Tanner di Kota Surakarta”, Skripsi, Surakarta: Fakultas Teknik Jurusan Sipil Universitas Sebelas Maret.

Syafi'I, Rusydy, I., \& Handayani, D.,2018. "The Influence of Freight Transportation on Road Network Performance in Surakarta", AIP Conference Proceedings, 1977(1), 040016. https://doi.org/10.1063/1.5042986

Syafi'I, Santoso, M. B., \& Handayani, D., 2018, “The Origin-Destination Matrix for Freight Transportation with Bayesian Inference Method", AIP Conference Proceedings, 1977. https://doi.org/10.1063/1.504298

Tamin, O. Z., 2000, "Perencanaan dan Permodelan Transportasi”, ITB press, Bandung.

Trisnawati, N., Syafi'I, \& Handayani, D., 2018, "Forecasting of Origin-Destination Matrix of Freight Transportation of Surakarta with Maximum Likelihood Method", AIP Conference Proceedings, 1977. https://doi.org/10.1063/1.5042989 